\title{
And the gentlemen went there two by two
}

\section{Bernard Stonehouse}

Voyage Through the Antarctic. By Richard Adams and Ronald Lockley. Pp.160. UK ISBN 0-7139-1396-7; US ISBN 0-394-52858-1. (Allen Lane/Knopf: 1982.) $£ 8.95, \$ 13.95$. Antarctic Wildlife. By Eric Hosking and Bryan Sage. Pp.160. ISBN 0-7099-1215-3. (Croom Helm/Facts on File: 1982 .) $£ 12.95, \$ 22.95$.

ANTARCTICA and the Southern Ocean are among the few remaining bastions of wildlife, though with a long history of depredation at the hands of human beings. Southern fur seals were hunted almost to extinction on the peripheral islands in the eighteenth and nineteenth centuries, and whale stocks devastated in the present century. Elephant seals and even penguins were boiled by the thousand for the golden oil in their blubber. Now the killing of the larger animals has almost stopped; attention turns to harvesting the fish and krill that will form man's final bonanza from the Antarctic.

For many years scientists and their support teams had sole rights of travel in the far south. Today tour ships are regular visitors, loaded with enthusiastic passengers who saw Alaska last year, the Galapagos the year before, and are now doing Antarctica. Tourists on the hallowed ground where Scott, Amundsen and Byrd once stood? Yes, and good luck to them. Nowhere in the world is the scenery grander and less spoiled by human artefacts; nowhere do seals and seabirds gather in more spectacular concentrations; and nowhere are wild animals more readily approachable by nature-lovers with camera, notebook and wide-eyed wonder. The two books reviewed here arose from tours laid on by Lindblad Travel, one of the earliest operators to brave the fury of stormy seas, elitist scientists and anxious administrators to take ordinary people (well, ordinary wealthy people) to the Antarctic. As a result, thousands have seen the southern wonderland who would otherwise have been excluded, and there are correspondingly more who can write about it, read about it and, if necessary, root for it from first-hand knowledge.

Voyage Through the Antarctic, the smaller and cheaper volume, is the narrative of a journey from Tierra del Fuego to Stewart Island, New Zealand, via the South Shetland Islands, Antarctic Peninsula, Peter I $O \mathrm{y}$ and the edge of the

\section{Poles apart}

Wildlife in the Arctic, specifically the polar bear. is the subject of Lords of the Arctic by Richard C. Davids with photographs by Dan Guravich. The book is an account of scientific observations, conservation problems and the authors' experiences in their search for this elusive animal. Published by Macmillan. New York, Lords of the Arctic costs \$29.95.
Pacific sector pack ice, calling at McMurdo Sound, skirting Cape Adare and the Balleny Islands, and visiting Macquarie and Campbell Islands on the homeward run. Two generations ago this voyage would have been regarded as hazardous in the extreme; even now it is a voyage that polar scientists (myself among them) would be glad to experience for the research opportunities offered. Yet this and other trips like it are the stock-in-trade of tourist operators these days. Richard Adams, naturalist, novelist (Watership Down, Shardik, The Plague Dogs) and RSPCA luminary tells the plain tale, which naturalist and writer Ronald Lockley (Man against Nature, Orielton, Ocean Wanderers) embellishes with italicized passages of concentrated natural history.

This may well have been a practical way (perhaps the only way) of combining the talents of two celebrated writers who live far apart and write in widely-diverse idioms. For me the device fails; the two voices sing in different keys. Both authors are self conscious, Adams, the jolly tourist, Lockley, lyrical-authoritative; both have written far better, and neither rises fully to what could and should have been a splendid occasion. Peter Hirst-Smith's photographs too are disappointing. The few pages of colour glow excellently, but the many black-and-white prints spread through the text could have been selected more rigorously and printed less muddily; the best are fair, and the worst have a potato-print quality that does them no justice. But this is a good adventure story, with a lot of information and a deal of enthusiasm for Antarctica and its animals that make the book worthwhile.

Antarctic Wildlife is for me a much more satisfactory book, larger and almost fifty per cent dearer, but a far better production all round. This is not the story of a voyage; it is an account - indeed a celebration of Antarctic life, seen through the perceptive eye of Eric Hosking and discussed in scholarly but readable vein by Bryan Sage. The Old Master has lost none of his touch; these are superb photographs, printed to a high standard in both colour and black-and-white. I cavil only at a designer who on occasion lets the central gutter spoil the layouts unnecessarily. The seven chapters cover the historical background, continental, maritime and subantarctic ecology, and the life histories of penguins, albatrosses, other birds and seals; there is a final chapter on wildlife photography that many will find valuable. Antarctic Wildlife is an authoritative and beautiful volume, a book fit to match its subject.

Bernard Stonehouse is at the Scott Polar Research Institute, University of Cambridge, and editor of Polar Record.

\section{The natural history of mammals anew}

\section{I.J. Linn}

Mammals in the British Isles. By L. Harrison Matthews. Pp.208. ISBN 0-00-219738-3. (Collins: 1982.) £10.95.

A NEW title from the prolific pen of $\mathrm{Dr}$ Harrison Matthews is always a significant event in the world of theriology; and this is a new title, not merely a new edition of his earlier book, British Mammals, in the same New Naturalist series.

As both author and publisher are at pains to point out, the tremendous flowering of theriological literature which has taken place in the past 20 years or so has enabled the author to dispense with much of the basic introductory material which was necessary in the older book, and to follow through a specific line of thought with simplicity and clarity. That line is the one which amateur naturalist and professional zoologist alike contemplate with wonder and delight, namely the extraordinary detail and perfection of the adaptations of animals, in this case British mammals, to the environments in which they live. It is the line of thought which has given us the academic disciplines of sociobiology and behavioural ecology, and it also generates many of the questions which thinking people of many differing ages and backgrounds ask of biologists questions which are often very difficult to answer. This book will help all of these people.

Dr Matthews lays a firm foundation by spending most of the first third of the book reviewing the geological, climatic and human influences which have shaped the range of habitats available to British mammals. He then goes on to write lucidly and effectively about the various facets of ecology and behaviour which define a mammal's adaptivity, presenting hard scientific information and modern theory in a palatable and easily absorbed manner.

The book as a whole is spiced by $\mathrm{Dr}$ Matthews's trenchant and perceptive comments upon humanity, past and present. It is an excellent introduction to the natural history of British mammals for anyone, amateur or professional, who is interested in real animals in the real world.

Ian Linn is Senior Lecturer in Biological Sciences at the University of Exeter, and a founder member of the Mammal Society. 